\title{
Resource Rents and Dependence in Sub-Saharan African Countries Economies
}

\author{
Daniel Chibueze Onyejiuwa \\ Samuel Adegboyega University, Ogwa, Nigeria \\ Email: danielchibueze@gmail.com
}

Received 18 March 2016; accepted 1 April 2016; published 5 April 2016

Copyright (C) 2016 by author and OALib.

This work is licensed under the Creative Commons Attribution International License (CC BY). http://creativecommons.org/licenses/by/4.0/

(c) (i) Open Access

\section{Abstract}

Generally, natural resources among sub-Sahara African countries have been a subject of concern in Africa and across the world. As a means of capital accumulation in developing countries, natural resources have been considered as catalysts for economic growth. Almost all of the sub Saharan countries are developing countries, and natural resources are the main source of economic growth in these countries. This study assesses the evidence of resource curse in sub-Saharan African countries and the study uses secondary annual data. In order to realize the research purpose, resource dependence measured by the share of total export to GDP and resource rents were used, and identified its effect on real GDP. The paper focuses on answering these three questions: whether resource rents have retarded growth in SSA, which is the effect of dependence on natural resources and can resource curse exist in sub-Saharan African countries despite endowment in natural resources? The result showed that merchandized exports at current values, coefficient value of 0.14 and natural resource rents at current values, coefficient value of 0.08 , are positively significant with real GDP. However, the lagged value of natural resource rents, coefficient value of -0.06 , is negatively significant with real GDP. It was found that there is no evidence of Dutch disease and rent seeking at current values, but it is evident at past values. It implies that there is no evidence of resource curse at the current period, however it was largely surfaced in the proceeding period. The non-inclusion of other SSA countries that are not endowed with natural resources made the study limited to few SSA countries. The study tends to support the notion that resource-rich SSA countries are better off in short-run than in long-run.

\section{Keywords}

Resource Curse, Resource Dependence, Resource Rents, Exports, Economic Growth

Subject Areas: Economics

\section{Introduction}

Natural resources among sub-Sahara African countries (SSA) have been a subject of concern in Africa and 
across the world. The question is whether natural resource translates to economic growth or not. Natural resources are believed to be catalyst for economic growth if manage appropriately. It serves as means for capital accumulation for developing countries to position their economy at the steady rate of growth. Although, there seems to be two different perspectives on natural resources and economic growth relationship. Some studies followed the Benign perspective that posited that natural resource would assist the developing countries to transit from the stage of underdevelopment to that of industrial "take-off", as obtained in such countries as Britain, United States of America, Russia, and Australia (Baghebo, [1] and Rosser, [2]). Others had the view of Malign perspective that there exists a negative relationship between natural resource and economic growth. The latter perspective explains economic and development ills referring to as resource curse in literature (Pendergast, Clark and Kooten [3]).

Although some studies argued that African showed resource curse based on the parameters that was investigated, others have contrary view of a blessing rather than a curse. Resource curse can be attributed to the high degree of ethnic fragmentation that is inherent in the continent. Collier and Gunning [4] argued that institutional weakness is the main reason why Africa growth drivers are lacking, while Sachs and Warner [5] also pointed that the role of geography leads to the curse the aspect of geography in their study includes exposure to malaria and other diseases as well as the tendency to develop a high dependence on natural resources. Artadi and Sala-i-Martin [6] considered a number of robust determinants of growth and showed that in spite of the abundance of natural resources in African countries, they still performed significantly worse when compared with other developing regions. On the contrary, African bank [7] posited that resource-endowed African countries are richer (in terms of revenues, GDP and per capita GDP) than their resource-scarce counterparts. Cavalcanti Mohaddes and Raissi [8] argued that resource abundant is a factor of economic growth. Perreto [9] observed that growth regressions that ignored the endogeneity of initial income do not provide sufficient information to assess the evidence of resource curse. However, the study supported a positive correlation between resource and growth.

Some comparable evidence showed that some resource-endowed countries have robust economy as a result of endowment in natural resources, while some countries' growth rate retard. About three decades ago, Indonesia and Nigeria were heavily dependent on oil revenue, and Nigeria had comparable higher per capita incomes than Indonesia. However, in recent times Indonesia's per capita income is two times that of Nigeria's. Nigeria's per capita income in real value has shown a slow growth trend over the years unlike Indonesia (World Development Indicators, 2014). Although Indonesia is not among SSA countries, but it compared with Nigeria showed that another resource-rich country from a different region cannot be characterized with low growth rate in its per capita income. Both Central Africa Republic and Botswana are rich in diamonds. Botswana has had an average growth rate of 4.2 percent between 1981 and 2012, but Central Africa Republic has plunged into civil strife over control of its diamond and national wealth.

Despite having substantial natural resources that can spur economic development, many resource-rich countries in Sub-Saharan Africa (SSA) are faced with slow pace of economic growth and development. This is consequent on what have been referred to in the literature as a "resource cure" hypothesis (Sachs \& Warner, [10]; Auty, [11]; Sala-i-Martin \& Subramanian [12]; Bulte, Damania \& Deacon, [13]). According to Gelb ([14]), availability of natural resources and any consequent boom should bring about economic growth and general improvement in the wellbeing of the people of SSA countries. However, this does not appear to be the case in natural resource rich sub-Saharan African countries. Rather, natural resource availability and its boom negatively correlate with growth in SSA countries.

There are numerous reasons that natural resource endowment has not translated into economic growth in SSA countries which also can be applicable to other regions in the world. Among them are: Dutch disease, rent seeking and patronage, non-implementation of capital and social projects and government non-productive spending. Importantly, these obstacles have been evident in different dimensions and with different faces in respective countries, regions and communities. Many reasons have been advanced for this negative relation that exist between resource endowment and economic growth but little emphasis whether it visible at current periods or at latter periods. Therefore, it is important to explain the relation between natural resource and economic growth by examining the dynamic nature of factors such as resource rents and dependence on export of natural resources.

The study therefore addresses whether resource rents has retard growth in SSA, what are the effect of dependence on natural resources and can resource curse exist in sub-Saharan African countries despite endowment in natural resources? In attempt to address these questions, the study attempt to examine the effect of resource export 
on economic growth in sub-Saharan African countries, identify the effect of resource rents on SSA economic growth and assess the evidence of resource curse in sub-Saharan African countries;

The scope of study concentrates on 12 resource-rich Sub-Saharan African Countries that data are available and covers the period of 1981 to 2013. We have Time $(\mathrm{T})=33$, observations covering 12 countries $(N)$ and total observations, $\mathrm{n}=396$ (that is, $\mathrm{n}=\mathrm{T}$ multiply by $\mathrm{N}$ ). A list of SSA countries is provided in Appendix 1 .

\section{Related Literature}

\subsection{Theoretical Literature}

Most economists believed that trade is generally seen as a fulcrum of growth and has been given much emphasis. In the 17th century, a group of merchants, government officials and philosophers who advocated on economic philosophy known as mercantilism started the notion that international trade brings economic growth and increases the welfare of a nation. It is believed that a nation to become powerful, it export is expected to be more than it import, where the resulting export surplus is used to purchase precious other valuables. Adam Smith propounded the classical theory of international trade based on his concept of absolute advantage idea. According to him, the true wealth of a nation are stock of human, man-made and natural resource rather than stock of precious metals, and he went further to argued that the wealth of a nation can be increased if the government would increase their volume of exports that give them absolute advantage. In addition, he showed the gains of trade that it is possible to make a nation better off without making another worse off (Debel, [15]). The growth of any economy depended largely on the volume of exports to other countries and this economic idea fosters countries to discover more and more resource to export [15].

Comparative advantage model propounded by David Ricardo to replace the principle of absolute advantage, provided a strong basis for trade among countries. According to this model, a country will specialize in the production and exportation of commodity of which it has comparative advantage over other countries. That is the commodity that it can produce at the lowest relative cost. The principle of reciprocal demand developed by J.S. Mill and later developed by Edgeworth and Marshall explained both demand and supply conditions which determine the terms of trade and hence trade between countries. The factor endowment theory of Eli Hecksher \& Berti Ohlin (H-O) of external trade posited that different relative proportions of countries have different endowments of factors of production later replaced the comparative advantage. Some countries have large amounts of capital (capital intensive) while others have little capital and much labour (labour intensive). This theory argued that each country has a comparative advantage in the commodity which uses the country's abundant factor. Capital intensive countries should specialize in the production and export of capital-intensive goods while labour intensive countries should specialize in the production and export of labour-intensive commodities. This theory encouraged third world countries to focus on their labour and land intensive primary product exports. However, it was argued that by exchanging these primary products for manufactured goods of the developed countries, third world nations could realize enormous benefits obtained from trade with the richer nations [15]. The development of these theories shaped the interest of countries to concentrate on increasing production of resources they have comparative advantage, high demand and factor intensive over other countries. On this stance, resource endowed SSA countries focus is to increase their output level by increasing production and exportation of natural resource of which they are endowed. The increase in natural resource production is believed to increase aggregate income, and thereby lead to economic growth [15].

\subsection{The Benign Perspective: Natural Resource Abundance Beneficial to Growth}

The notion of natural resource leading to economic growth and development is a conventional perspective that existed before the late $80 \mathrm{~s}$ ([2], Akinlo, [16]). This view was shared by many development theorists and neoliberal economists until the renaissance of new view in the $1980 \mathrm{~s}$ who claimed that natural resource abundance was not a blessing to the developing countries. The underlying argument of the benign perspective is that natural resource endowment would assist the developing countries to transit from the stage of underdevelopment to that of industrial "take-off", as obtained in such countries as Britain, the United States and Australia.

\subsection{The Malign Perspective: Natural Resource Abundance Not a Blessing}

The poor performance of most resource-endowed countries in the 1980s experiencing low economic growth and 
development is hampered due to the 'resource curse' phenomenon [16]. [10] argued that natural resource abundance is harmful to growth which was as a result of many inherent factors. Extensive literature exists on the various channels through which natural resources, especially oil, harm growth. The major transmission mechanisms include Dutch disease, volatility argument and inefficiency in resource allocation argument, rent seeking activities, patronage and weak institutions.

The general argument is anchored on the fact that revenues from natural resources are very volatile, as they are driven by sharp and significant fluctuations in prices over relatively short periods of time [16]. Consequently, in the face of fluctuating revenues, governments in the resource-endowed countries often find it extremely difficult to pursue a prudent fiscal policy. In addition, there is the general apprehension that windfall revenues arising from unanticipated high export prices would be used for consumption rather than being invested. Moreover, the activities of entrepreneurs engaging in rent seeking withdraw the economy productive rather than being unproductive. The existence of elite and political class destroys strong institutions that will check and balance political office holders' excessiveness, which may cause high profile corruption.

\subsection{Empirical Literature}

\subsubsection{Resource Abundance as a Blessing}

[2] and Wright and Czelusta [16] studies argued that resource curse is not an inevitable outcome of oil, gas or mineral windfall revenues. They have cited examples of countries for which natural resources have been a "blessing" rather than a curse. These countries are Norway, Botswana, United State of America, Malaysia and Indonesia. According to their findings, these countries were able to translate their resource to economic growth on the basis of proper management and efficient appropriation of resource, absence of ethnic fractionalization, absence of corruption and weak institutions. According to [9], correlation between resource abundance and the initial level of GDP per capita showed that it is positive. The study argued that it is not at all obvious that resource abundant countries are worse off, rather, better off in terms of per capita income. The study also posited that the specifics of the growth model that any study uses to interpret the regressions are of paramount importance and should be discussed explicitly to avoid misleading results. Rodriguez and Sachs [17], developed a fully specified simulation model of the Venezuelan economy and found out that country's growth experience is due to the fact that the discovery of oil allows it to live beyond its means, which means that it converges to the steady state of the economy from above. That is, it will continue to decrease, in terms of growth, until it converge to the stationary state.

[12] discovered that upon controlling for institutional quality, natural resources are not significantly negatively related to economic growth. They also showed that the effect of natural resources depends on the particular ones being considered. Fuel and mineral resources negatively impact institutions (and hence economic growth), but the relationships between economic growth and other types of resources are generally found to be statistically insignificant. This is an important finding, because it suggests that the curse of natural resources may really be a curse of particular natural resources. Papyrakis and Gerlagh [18] study, upon taking corruption, investment, openness of the economy, terms of trade and schooling into account, found natural resource abundance to have a positive impact on growth. This finding supported the claim of studies arguing that natural resource endowment provides huge means of revenue for capital accumulation and positioning of the economy to balanced path rather retarding the economy.

\subsubsection{Resource Endowment/Abundance as a Curse}

Many prominent researchers have supported the view that resource-poor countries have better economic growth and development indicators than resource-rich countries. [10] made a major contribution in natural resource curse discussion when they found a negative relationship between natural resource abundance and growth in a large cross-country study, and 1997 and 2001 extension empirically showed that a higher dependence on natural resources reduces subsequent economic growth in a large cross section of countries. Research findings have since considered the natural resource curse hypothesis and theories from different points of view. For instance, Jensen and Wantchekon [21] and Hodler [22] argued that there exist negative associations between resource abundance and the stability and quality of the political system, while Auty [19] and Auty [20] explained the curse historically. Norman [23] discovered that larger initial natural resource stocks increase the levels of lawlessness and do not affect growth directly, while raw resource exports do not significantly affect the role of law 
but do affect average growth rates. Barro and Sala-i-Martin [24] and Mankiw. Romer and Weil [25] estimated that adding measures of resource abundance to the conditional convergence growth models brings about evidence for the resource curse.

[20] suggested that resource abundant countries, especially developing countries including most sub-Saharan African countries, may not be benefiting economically from the perceived comparative advantage from such resource. Additional argument for the resource curse hypothesis is found in Naidoo [26], who measured extraction of forest resources using forest area cleared during the period 1960-1999. He found a negative association between the liquidation of forest resources and economic growth rates. Again, this measure may really reflect the degree to which a country is dependent on natural resources. [26] controls for the absolute size of a country (to distinguish large, resource poor countries from small, resource rich ones), but failed to control for the impact of population when measuring a country's resource dependence (resource dependence measured resource export as the share of total exports). Cotet and Tsui [27] gave a good account of relationship that exists between natural resource and economic development. Their study found a little robust evidence of a negative relationship between oil endowment and economic performance by relating it to Malthusian trap of population theory that states that population grows geometrically, while output grows arithmetically.

Carmignani and Chowdhury [28] argued that sub-Saharan African (SSA) countries are indeed special case where resource dependence retard growth whereas it improved growth in other regions. They posited natural resources curse is specific to SSA countries and does not depend on the type of primary commodities on which SSA countries specializes. But instead, the SSA countries specificity appears to arise from the interaction between institutions and natural resources. From Jones [29] empirical findings, he established that there is no robust evidence for a growth curse that is particular to natural resources but as a factor of weak institution. [3] gave an extensive research on the subject matter. Their technique involved 101 countries of different levels of economies across the globe including some resource-endowed SSA countries. They focus on resource rents and rent-seeking behaviour, arguing that rent seeking affects corruption and that, in turn, impacts wellbeing. Their measure of wellbeing is the Human Development Index, although they find similar results for per capita GDP and conclude empirically that resource abundance does not directly impact economic development.

\section{Methodology}

\subsection{Theoretical Framework}

This study adopted the Benign perspective as the theoretical framework. As identified in the literature, this perspective has the view that natural resources had positive effect on economic growth [1] [2] [16]. The major channels through which resource endowed could have a positive relationship with economic growth are numerous. One, the huge revenues from natural resource enabled the SSA country governments of various natural resource producing countries to spend and invest massively on capital accumulation and long-term projects without depending on taxation. Revenues from natural resource sales, if properly utilized, could serve as a "big push" for economic growth and even economic development [16]. This channel is especially important for developing countries where dearth of capital often constitutes a major hindrance to growth and development.

\subsection{Model Specification}

The model employed in this study is multiple regression panel data models. Presenting a Long-run output growth functional relationship:

$$
\mathrm{RGDP}=f(\text { mex }, n r r)
$$

where GDP is real Gross Domestic Product (GDP), mex is Merchandized Export, $n r r$ is Natural resource rents and $f$ is functional notation. For the purpose of statistical test, the log linear representation of (12) a is thus:

$$
\ln g d p_{i t}=\theta_{0 i}+\theta_{1 i} \ln \text { mex }_{i t}+\theta_{2 i} \ln n r r_{i t}+\mu_{i}+\epsilon_{i t}, i=1,2, \cdots, N ; t=1,2, \cdots, T
$$

where $\operatorname{lngdp_{it}}$ is the natural $\log$ of real GDP per capita over period $t$ in generic country $i, \operatorname{lnmex}_{i t}$ is the natural $\log$ of Merchandized Export per capita, Innrr ${ }_{i t}$ is the natural log of Natural resource rents per capita over the cross countries and time periods. With $\theta_{0 i}$, denoting country specific fixed effects. The econometric specification does not imposed homogeneity of the depreciation rate, $\delta_{i}$, or the growth rates of labour, $n_{i}$ and technology, 
$g_{i}$, which is accommodated through the fixed effects. $\mu_{i}$ which is the error term, capture the individual cross-sectional units unobserved effects. The idea behind the per capita value to all variables is to capture growth in per capita terms that expresses the economic growth.

If the variables are cointegrated, then the error term is $I(0)$ for all $i$. The ARDL $(1,1,1)$ dynamic panel specification of (3.2) of the study is

$$
\lg d p_{i t}=\delta_{01 i}+\delta_{10 i} \operatorname{lmex}_{i t}+\delta_{11 i} \operatorname{lmex}_{i t-1}+\delta_{20 i} \ln r r_{i t}+\delta_{21 i} \ln r r_{i t-1}+\gamma_{i} g d p_{i, t-1} \mu_{i}+\epsilon_{i t}, i=1,2, \cdots, N ; t=1,2, \cdots, T
$$

The error correction reparameterization of (3.3) is

$$
\Delta \lg d p_{i t}=\Psi\left(\operatorname{ldrv}_{i, t-1}-\theta_{0 i}-\theta_{1 i} \operatorname{lmex}_{i t}-\theta_{2 i} \ln r r\right)+\delta_{11 i} \Delta \operatorname{lmex} x_{i t-p}+\delta_{21 i} \Delta \ln r r_{i t-p}+\tau_{i} \Delta \lg d p_{i, t-1}+\epsilon_{i t}
$$

where

$$
\Psi_{i}=-\left(1-\gamma_{i}\right), \theta_{0 i}=\frac{\mu_{i}}{1-\gamma_{i}}, \theta_{1 i}=\frac{\delta_{10 i}+\delta_{11 i}}{1-\gamma_{i}}, \theta_{2 i}=\frac{\delta_{20 i}+\delta_{21 i}}{1-\gamma_{i}}
$$

The error-correction speed of adjustment parameter, $\Psi_{i}$, and the long-run coefficients, $\theta_{1 i}$ and $\theta_{2 i}$ are of primary interest. With the inclusion of $\theta_{0 i}$, a nonzero mean of the cointegrating relationship is allowed. One would expect $\Psi_{i}$ to be negative if the variables exhibit a return to long-run equilibrium which corrects the error associated in short-run across countries.

The study employed Autoregressive Distributed Lag (ARDL) Dynamic Panel Data (DPD) model for their estimations. The dynamic fixed effects (FE) estimation approach is used in which the time-series data for each group are pooled and only the intercepts are allowed to differ across groups. The traditional dynamic fixed effect using stata command, xtreg, is be used to estimate the autoregressive distributed lag (ADRL) dynamic panel data model (Blackburne \& Frank, [30]). By Distributed lag Model, we mean the inclusion of more than one lag of the regressor in a regression function; the model help to determine the effects of a change in a policy variable over another (Shittu, Yemitan \& Yaya, [31]).

\section{Data Presentation and Discussion of Results}

\subsection{Unit Root Tests}

It is important to make sure that there is no mixture of $\mathrm{I}(0), \mathrm{I}(1)$ and $\mathrm{I}(2)$ variables so that we make sensible interpretation of the long-run relationships. Therefore panel unit roots tests is of very importance

Table 1 reported the IPS for variables under study. IPS test on all variables are appropriate, and all variables is stationary at first difference at $1 \%$ level after showing non-stationarity at level at $1 \%$ level. Thus, we can safely regard all the variables as being I(1) and not worry about dealing with a mixture of I(1) and I(2) variables in our model. For all of our variables log-level and without a trend were used.

The implication of these results suggest that co-integration test must be carried out to ascertained whether there is long-run relationship that exist between the dependent variable (real GDP per capita) and the independent variables (natural resource rents per capita and total merchandized exports per capita). Also, Error Correction Model to return to long-run equilibrium which corrects the error associated in short-run across countries.

\subsection{Co-Integration Tests}

The co-integration test result reported in Table 1 is based on the Pedrono's residual co-integration test that has 7

Table 1. Im, pesaran and shin unit root tests for variables.

\begin{tabular}{cccl} 
Variables & \multicolumn{2}{c}{ IPS Test } & Remark \\
\cline { 2 - 3 } & $\mathbf{I}(\mathbf{0})$ & $\mathbf{I}(\mathbf{1})$ & stationary at first difference \\
Real GDP per capita & -0.6031 & $-4.514^{* * *}$ & stationary at first difference \\
Natural Resource Rents per capita & -0.9099 & $-5.180^{* * *}$ & stationary at first difference \\
\hline Total Merchandized Exportsper capita & -1.0524 & $-5.826^{* * *}$ & .
\end{tabular}

Source: Author's calculation, 2015 . Note: significant at ${ }^{*} 10 \%,{ }^{* *} 5 \%$ and ${ }^{* * *} 1 \%$ levels for all statistics. Critical value for IPS unit root tests for $10 \%$, $5 \%$ and $1 \%$ respectively are, $-1.810,-1.900$ and -2.040 . 
statistics of which 6 is adopted and the Kao residual based co-integration test.

In the results in Table 2, it showed that the null hypothesis of no co-integration is rejected at $1 \%$ level of significance in 6 statistics and non-significance in group rho-statistic. Therefore, the assumption that the long-run parameters for the variables in their levels are equal to the short-run parameters for the variables in their differences is accepted and they showed a strong evidence of co-integration relation. This suggest that there is long-run equilibrium relationship that exist between log of GDP per capita and log of natural resource rents per capita and log of total merchandized exports per capita.

\subsection{Hausman Tests for Fixed and Random Effect}

The Hausman test is consistent and efficient for Fixed and inconsistent for Random Effect. This invariable suggest that fixed effect estimator is consistent and preferred in ADRL Dynamic Panel Data long-run estimation. The advantage of fixed effect over random effect can be as a result of the correlation between the unobserved heterogeneity of individual SSA countries captured by the error term, $\mu_{i}$ and the explanatory variables. Fixed effect estimator corrects the serial correlation in the models, when $E\left(X_{j i t} v_{i}\right) \neq 0$.

\subsection{Long-Run Level Estimation, ADRL Dynamic Panel Fixed Effects Model}

From the results estimated in Table 3, it showed that log of total merchandised exports per capita (mex), log of natural resource rents per capita (nrr), log of real GDP per capita at lag 2 and log of natural resource rents per capita at lag 1 are significant at $5 \%$ level of significance, except log of total merchandised exports per capita at lag 2 that is not significant. All the independent variables are positive related except log of natural resource rents per capita at lag 1 that has a negative slope. It is also reported in Table 3 that correlation coefficient that measure the goodness of fit is high, valued at 0.93 . It indicates that the variations in real GDP is explained by the independent variables by $93 \%$, and the overall statistic, F-statistic value at 270 , is significant at $1 \%$ level of significance.

The results implied that a positive change in mex at current time, real GDP will respond proportionally by $14 \%$, while a proportional increase in nrr will increase real GDP by $8 \%$. On the basis of regressing current values

Table 2. Co-integration tests.

\begin{tabular}{ccc}
\hline Statistic & Value & Significance level \\
\hline Panel rho & $-1.757^{* * *}$ & $5 \%$ \\
Panel PP & $-7.328^{* * *}$ & $1 \%$ \\
Panel ADF & $-7.209^{* * *}$ & $1 \%$ \\
Group rho & -0.480 & Not significant \\
Group PP & $-8.714^{* * *}$ & $1 \%$ \\
Group ADF & $-8.027^{* * *}$ & $1 \%$ \\
Kao & $1.97^{* *}$ & $5 \%$ \\
\hline
\end{tabular}

Source: Author's calculation, 2015.

Table 3. Long-run level estimations.

\begin{tabular}{ccc}
\hline Log of real GDP as dependent variable & Coefficient & Standard Error \\
\hline Constant & $0.957^{* * *}$ & 0.182 \\
Log of merchandised exports per capita & $0.139^{* * *}$ & 0.018 \\
Log of natural resource rents per capita & $0.081^{* * *}$ & 0.015 \\
Log of lagged value of natural resource rents per capita & $-0.060^{* * *}$ & 0.015 \\
Log of lagged value of merchandised exports per capita & 0.002 & 0.020 \\
log of lagged value of real GDP per capita) & $0.740^{* * *}$ & 0.036 \\
$R^{2}=0.93 ;$ F-statistics $=270^{* * *}$ & &
\end{tabular}

Source: Author's calculation, 2015 . Significant at ${ }^{*} 10 \%,{ }^{* *} 5 \%$ and ${ }^{* * *} 1 \%$ levels for all statistics; standard error in parenthesis. 
of natural resource rents on the current value of real GDP, the assertion of resource curse by [10] and [5] and other studies that found resource curse in SSA will not hold. From the results, endowment in natural resource will significantly increase income. [8] study support this claim of no evidence of resource curse. The negative relationship of distributive lag of log of natural resource rents per capita with log of GDP per capita implied that any proportional increase in the past values of nrr will proportionally decrease the real GDP by $6.2 \%$. It is obvious form the estimated result that past value of natural resource rents has negative effect on the real aggregate output. This results show evidence of resource curse in SSA when the past value of natural resource rents is related to economic growth.

The dynamic factor of all models showed a positive relationship with real GDP and significant at 5\% level. The inclusion of lagged of log of real GDP per capita into the models is to account for the dynamism of the model. That is, how the dependent variable are been affected by its past values. The coefficients of lagged value of real GDP, 0.74, indicated 74\% proportional increase response by real GDP when it's previous values rise. This suggests that past aggregate output level has a big positive impact on the current aggregate output.

Acknowledging the non-stationary of the variables at their lag specifications, and their stationarity at first difference and establishing panel co-integration in all models, the Panel Error Correction Model (PECM) can be estimated. As identified earlier, the purpose of the PECM is to correct the error associated in short-run across countries. The coefficients of lagged value of errors must be negative to cause a return to long-run equilibrium.

\subsection{Panel Error Correction Model (PECM)}

The PECM estimate is of great importance because it shows the short-run relationships of variables. The coefficients of the error term have negative slopes and are significant at $1 \%$ level. This suggests that the error associated in short-run across countries has been corrected, and there is a return to long-run equilibrium (Table 4).

The PECM results showed that all the independent variables are significant though with different signs. The negative slope of the lagged value of natural resource rents an evidence of resource curse on past value in the short-run. However, at current values of both merchandised exports and natural resource rents, they are positively related to real GDP in short-run.

\section{Summary, Recommendations and Conclusion}

\subsection{Conclusion}

It was empirically found that in the long-run relationship, the evidence of resource curse could not be established when economic growth depends on the current values of merchandized export and natural resource rents. However, the inclusion of lagged values of natural resource rents established the evidence of resource curse. These findings showed that in the absence of strong socio-political institutions and good policy-driven economic growth, the once-a-blessing resource will later become a curse. The only SSA country exception that has been able to solve substantial macroeconomic problems associated resource is Botswana. For five decades, Botswana has had virtually uninterrupted rapid growth which has lifted them from one of the world's most impoverished

\begin{tabular}{|c|c|c|}
\hline$\Delta\left(\operatorname{lgd} p_{\mathrm{it}}\right)$ & Coefficient & Standard Error \\
\hline Constant & $0.019^{* *}$ & 0.009 \\
\hline$\Delta$ (log of merchandised exports per capita) & $0.051^{* * *}$ & 0.013 \\
\hline$\Delta$ (log of natural resource rents per capita) & $0.058^{* * *}$ & 0.011 \\
\hline$\Delta$ (log of lagged value of natural resource rents per capita) & $-0.038^{* * *}$ & 0.011 \\
\hline$\Delta$ (log of lagged value of merchandised exports per capita) & $0.027^{* *}$ & 0.014 \\
\hline$\Delta$ (log of lagged value of real GDP per capita) & $0.267^{* * *}$ & 0.071 \\
\hline Error correction term at lag 1 & $-0.189^{* * *}$ & 0.055 \\
\hline \multicolumn{3}{|l|}{$R^{2}=0.1811$} \\
\hline F-statistics $=11.39^{* * *}$ & & \\
\hline
\end{tabular}

Source: Author's calculation. Notes: $\Delta$ (real GDP) is dependent variable. Significant at ${ }^{*} 10 \%,{ }^{* *} 5 \%$ and ${ }^{* * *} 1 \%$ levels for all statistics; standard error in parenthesis. 
countries into the ranks of the upper-middle-income nations. This has accredited to their ability to formulate policy and prudently managing its mineral wealth that enable them to avoid the resource curse (Lundgren, Alun and York [32]). Therefore, it is essential for government and policy makers of these SSA countries to guard judiciously against any factor that will cause a decline in their manufacturing sector and ultimately, low or slow economic growth.

\subsection{Recommendations and Policy Implications}

The following recommendations are suggested.

1) Resource endowed SSA countries should utilized all available natural resources and propel to growth through diversification of their economy where agriculture, agro-allied industries and the entire manufacturing sector would continue to contribute to their economy.

2) Resource endowed SSA countries should formulate policy that will in turn accelerate the economic growth and good management of natural resources in SSA countries.

3) Resource-endowed SSA countries' agenda should be to drive their macroeconomic policy towards a supporting sustained and broad-based development.

4) On the other hand, resource endowed SSA countries' policymakers should address managing natural resource wealth on how much of the resource wealth to consume now and how much to consume later to place them on balanced growth path. Botswana has earned a reputation for good governance and prudent macroeconomic policies. They pursued 'inclusive institutions' policy which has helped them drive economic performance over the last decades.

5) The volatility of resource prices should make resource endowed SSA countries' government cautious when choosing between investments in physical or financial assets because physical assets cannot be liquidified immediately to address sudden drops in resource revenue.

6) Establishing institutional mechanisms or policy to reduce the adverse effects of volatile prices is therefore essential.

\section{References}

[1] Baghebo, M (2012) Natural Resource Economics. Kadmon Printing Press and Publishing House, Bayelsa.

[2] Rosser, A. (1999) The Political Economy of the Resource Curse: A Literature Survey. IDS Working Paper 268, http://www.ids.ac.uk/files/WP268.pdf.

[3] Pendergast, S.M., Clarke, J.A. and van Kooten, G.C. (2008) Corruption and the Curse of National Resources. Department of Economics, University of Victoria. http://www.economics.ca/2008/papers/0633.pdf

[4] Collier, P. and Gunning, J.W. (1999) Why Has Africa Grown So Slowly. Journal of Economics Perspectives, 13, 3-22. http://dx.doi.org/10.1257/jep.13.3.3

[5] Sachs, J.D. and Warner, A.M. (1999) The Big Push, Natural Resource Booms and Growth. Journal of Development Economics, 59, 43-76. http://dx.doi.org/10.1016/S0304-3878(99)00005-X

[6] Artadi, E. and Sala-i-Martin, X. (2003) The Economic Tragedy of the Xxth Century: Growth in Africa. NBER Working Papers 9865. http://www.nber.org/papers/w9865

[7] African Bank (2007) Africa’s Natural Resources: The Paradox of Plenty. http://www.afdb.org/fileadmin/uploads/afdb/Documents/Publications/\%28E\%29\%20AfricanBank\%202007\%20Ch4.p $\underline{\mathrm{df}}$

[8] Cavalcanti, T.V. de V., Mohaddes, K. and Raissi, M. (2011) Growth, Development and Natural Resources: New Evidence Using a Heterogeneous Panel Analysis. The Quarterly Review of Economics and Finance, QUAECO-649, 1-14. http://dx.doi.org/10.1016/j.qref.2011.07.007

[9] Perreto, P. (2008) Is the “Curse of Natural Resources” Really a Curse? ERID Working Paper, No. 14. www.resec.ethz.ch/content/.../resource.../SURED-08_Peretto.pdf

[10] Sachs, J.D. and Warner, A.M. (1995) Natural Resource Abundance and Economic Growth. NBER Working Paper No. 5398. http://www.nber.org/papers/w5398

[11] Auty, R.M. (2007) Natural Resources, Capital Accumulation and the Resource Curse. Ecological Economics, 61, 627-634. http://dx.doi.org/10.1016/j.ecolecon.2006.09.006

[12] Sala-I-Martin, X. and Subramanian, A. (2003) Addressing the Natural Resource Curse: an Illustration from Nigeria. National Bureau of Economic Research, Working Paper 9804, Cambridge, MA. 
www.econ.upf.edu/docs/papers/downloads/685.pdf

[13] Bulte, E.H., Damania, R. and Deacon, R.T. (2005) Resource Intensity, Institutions, and Development. World Development, 33, 1029-1044. http://dx.doi.org/10.1016/j.worlddev.2005.04.004

[14] Gelb, A.H. (1988) Oil Windfalls: Blessing or Curse? Oxford University Press, Oxford.

[15] Debel, G. (2002) Exports and Economic Growth in Ethiopia, An Empirical Investigation. M.Sc. Thesis, The School of Graduate Studies of Addis Ababa University, Addis Ababa.

[16] Akinlo, A.E. (2012) How Important is Oil in Nigeria’s Economic Growth? Journal of Sustainable Development, 5, No. 4. http://dx.doi.org/10.5539/jsd.v5n4p165

[17] Rodriguez, F. and Sachs, J.D. (1999) Why Do Resource-Abundant Economies Grow More Slowly? Journal of Economic Growth, 4, 277-303. http://dx.doi.org/10.1023/A:1009876618968

[18] Wright, G. and Czelusta, J. (2004) The Myth of the Resource Curse. Challenge, 47, 6-38.

[19] Auty, R.M. (1997) Natural Resource Endowment, the State and Development Strategy. Journal of International Development, 9, 651-663. http://dx.doi.org/10.1002/(SICI)1099-1328(199706)9:4<651::AID-JID474>3.0.CO;2-4

[20] Auty, R.M. (2001) Resource Abundance and Economic Development. Oxford University Press, Oxford.

[21] Jensen, N. and Wantchekon, L. (2004) Resource Wealth and Political Regimes in Africa. Comparative Political Studies, 37, 816-841. http://dx.doi.org/10.1177/0010414004266867

[22] Hodler, R. (2006) The Curse of Natural Resources in Fractionalized Countries. European Economic Review, 50, 13671386. http://dx.doi.org/10.1016/j.euroecorev.2005.05.004

[23] Norman, C. (2009) Rule of law and the Resource Curse: Abundance Versus Intensity. Environmental and Resource Economics, 43, 183-207. http://dx.doi.org/10.1007/s10640-008-9231-y

[24] Barro, R. and Sala-i-Martin, X. (1991) Convergence. Journal of Political Economy, 100, 223-251. http://dx.doi.org/10.1086/261816

[25] Mankiw, G., Romer, D. and Weil, D. (1992) A Contribution to the Empirics of Economic Growth. Quarterly Journal of Economics, 5, 407-437. http://dx.doi.org/10.2307/2118477

[26] Naidoo, R. (2004) Economic Growth and Liquidation of Natural Capital: The Case of Forest Clearance. Land Economics, 80, 194-208. http://dx.doi.org/10.2307/3654738

[27] Cotet, A. and Tsui, K. (2010) Resource Curse or Malthusian Trap? Evidence from oil Discoveries and Extractions. Ball University Economic Paper, 1-50. http://econweb.umd.edu/ davis/eventpapers/TsuiResource.pdf

[28] Carmignani, F. and Chowdhury, A. (2010) Why Are Natural Resources a Curse in Africa, but Not Elsewhere? http://www.uq.edu.au/economics/abstract/406.pdf

[29] Jones, S. (2008) Sub-Saharan Africa and the Resource Curse: Limitations of the Conventional Wisdom. DIIS Working Paper no 2008/14.

http://subweb.diis.dk/graphics/Publications/WP2008/WP08-14 Sub-Saharan Africa and the \%93Resource\%20Curse \%94.pdf.

[30] Blackburne, E.F. and Frank, M.W. (2007) Estimation of Nonstationarity Heterogeneous Panels. The Stata Journal, 7, 197-208.

[31] Shittu, O.I., Yemitan, R.A. and Yaya, O.S. (2012) On Autoregressive Distributed Lag, Cointegration and Error Correction Model (an Application to some Nigeria Macroeconomic Variables). Australian Journal of Business and Management Research, 2, 56-62.

[32] Lundgren, C.J., Alun, H.T. and York, R.C. (2013) Boom, Bust, or Prosperity? Managing Sub-Saharan Africa’s Natural Resource Wealth. International Monetary Fund, Washington DC. https://www.imf.org/external/pubs/cat/longres.aspx?sk=40476.0 


\section{Appendix 1: Sub-Saharan African Countries}

The below table shows the Sub-Sahara African Countries selected for this study, and their basis of selection depends availability of data for all variables.

Sub-Saharan African Countries Resource Dependence Ratio

\begin{tabular}{cccc}
\hline S/n & Resource Dependence SSA & Ratio $^{*}$ & Major Natural Resource(s) \\
\hline 1 & Botswana & 83 & Mineral resources \\
2 & Central Africa Republic & 41 & Oil \\
3 & Congo Dem. Republic & 97 & Mineral resources \\
4 & Chad & 87 & Oil \\
5 & Ghana & 43 & Mineral resources \\
6 & Niger & 50 & Mineral resources \\
7 & Nigeria & 97 & Oil \\
8 & Republic of Congo & 92 & Oil \\
9 & South Africa & 33 & Mineral resources \\
10 & Sudan & 95 & Oil \\
11 & Zambia & 80 & Mineral resources \\
12 & Zimbabwe & 45 & Mineral resources \\
\hline
\end{tabular}

Source: Author's compilation. Note: ${ }^{*}$ the value is calculated as the ratio of resource export to total export with data source, World Development Indicators, 2014.

Appendix 2

HAUSMAN TEST

\begin{tabular}{|c|c|c|c|c|}
\hline & \multicolumn{4}{|c|}{ Coefficients } \\
\hline & $\begin{array}{l}\text { (b) } \\
\text { fet }\end{array}$ & $\begin{array}{l}\text { (B) } \\
\text { ret }\end{array}$ & $\begin{array}{c}\text { (b-B) } \\
\text { Difference }\end{array}$ & sqrt (diag(V_b-V_B)) \\
\hline $\operatorname{lmex}$ & 0.1392816 & 0.1155809 & 0.0237007 & S0.E0. \\
\hline $\ln r r$ & 0.0810374 & 0.0922154 & -0.0111781 & 0.0076799 \\
\hline L2.lgdp & 0.7401962 & 0.933861 & -0.1936649 & 0.0026904 \\
\hline L2.lmex & 0.0016746 & -0.0572227 & 0.0588973 & 0.0328862 \\
\hline L.lnrr & -0.0596276 & -0.0770402 & 0.0174126 & 0.0114997 \\
\hline
\end{tabular}

$\mathrm{b}=$ consistent under Ho and Ha; obtained from xtreg

$\mathrm{B}=$ inconsistent under Ha, efficient under Ho; obtained from xtreg

Test: Ho: difference in coefficients not systematic

chi2 $(5)=(b-B)^{\prime}\left[\left(V_{-} \text {b-V_B }\right)^{\wedge}(-1)\right](b-B)=47.78$

Prob $>$ chi2 $=0.0000$ 